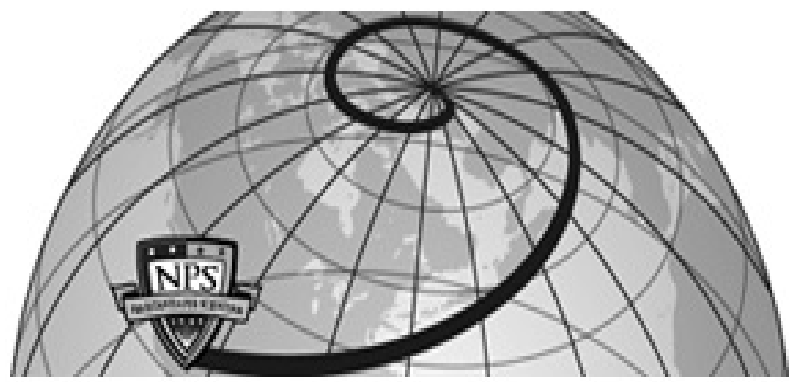

Calhoun: The NPS Institutional Archive DSpace Repository

\title{
An Evaluation of Privatized Military Family Housing: Lessons Learned
}

Cano, René Jr.

Monterey, California. Naval Postgraduate School

https://hdl.handle.net/10945/7314

Downloaded from NPS Archive: Calhoun

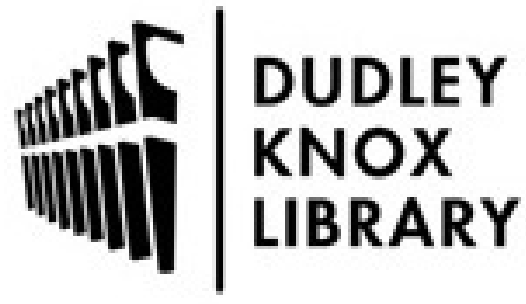

http://www.nps.edu/library
Calhoun is the Naval Postgraduate School's public access digital repository for research materials and institutional publications created by the NPS community. Calhoun is named for Professor of Mathematics Guy K. Calhoun, NPS's first appointed -- and published -- scholarly author.

Dudley Knox Library / Naval Postgraduate School 411 Dyer Road / 1 University Circle Monterey, California USA 93943 


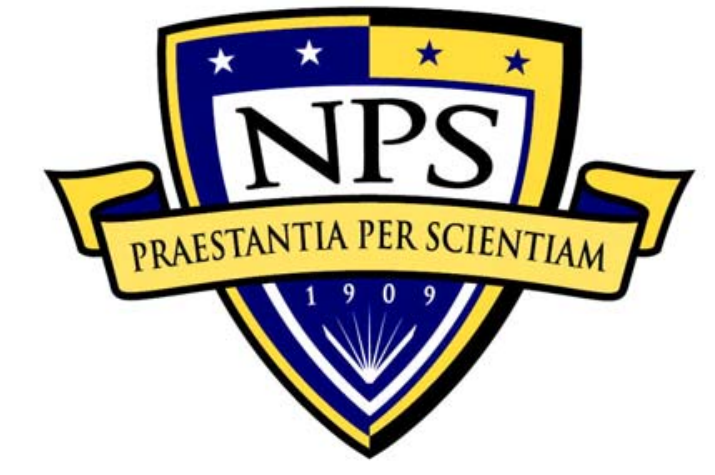

\section{NAVAL \\ POSTGRADUATE \\ SCHOOL}

MONTEREY, CALIFORNIA

\section{MBA PROFESSIONAL REPORT}

An Evaluation of Privatized Military Family Housing: Lessons Learned

By: René Cano, Jr.

June 2012

Advisors: Kenneth J. Euske,

Becky D. Jones 
THIS PAGE INTENTIONALLY LEFT BLANK 
Public reporting burden for this collection of information is estimated to average 1 hour per response, including the time for reviewing instruction, searching existing data sources, gathering and maintaining the data needed, and completing and reviewing the collection of information. Send comments regarding this burden estimate or any other aspect of this collection of information, including suggestions for reducing this burden, to Washington headquarters Services, Directorate for Information Operations and Reports, 1215 Jefferson Davis Highway, Suite 1204, Arlington, VA 22202-4302, and to the Office of Management and Budget, Paperwork Reduction Project (0704-0188) Washington DC 20503.
1. AGENCY USE ONLY (Leave blank)
2. REPORT DATE June 2012
3. REPORT TYPE AND DATES COVERED MBA Professional Report

4. TITLE AND SUBTITLE An Evaluation of Privatized Military Family Housing: $\quad$ 5. FUNDING NUMBERS

Lessons Learned

6. AUTHOR(S) Cano, René Jr.

7. PERFORMING ORGANIZATION NAME(S) AND ADDRESS(ES)

Naval Postgraduate School

Monterey, CA 93943-5000

9. SPONSORING /MONITORING AGENCY NAME(S) AND ADDRESS(ES) N/A

8. PERFORMING ORGANIZATION REPORT NUMBER

10. SPONSORING/MONITORING AGENCY REPORT NUMBER

11. SUPPLEMENTARY NOTES The views expressed in this thesis are those of the author and do not reflect the official policy or position of the Department of Defense or the U.S. government. IRB Protocol Number: N/A.

12a. DISTRIBUTION / AVAILABILITY STATEMENT

Approved for public release; distribution is unlimited

12b. DISTRIBUTION CODE

13. ABSTRACT (maximum 200 words)

An analysis of previous efforts to privative military housing and of the current privatization initiative revealed that long-term success requires flexibility to manage the private developers' and U.S. Government's exposure to various types of risks. The objective of this report is to identify how the Department of Defense has applied the lessons of early privatization efforts to manage risks and to guarantee success of the current Military Housing Privatization Initiative. Reviews of government reports, surveys, presentations, journal articles, and Congressional testimony were used to trace the progression of these privatization programs in order to highlight key lessons learned and provide a holistic perspective of the evolution of the privatization of military housing.

14. SUBJECT TERMS Base housing, Military Housing Privatization Initiative, Wherry, Capehart, Section 801, Section 802, risk management

15. NUMBER OF PAGES

16. PRICE CODE

17. SECURITY CLASSIFICATION OF REPORT

Unclassified

18. SECURITY CLASSIFICATION OF THIS PAGE

Unclassified
19. SECURITY CLASSIFICATION OF ABSTRACT Unclassified
20. LIMITATION OF ABSTRACT UU

Standard Form 298 (Rev. 2-89) Prescribed by ANSI Std. 239-18 
THIS PAGE INTENTIONALLY LEFT BLANK 
Approved for public release; distribution is unlimited

\title{
AN EVALUATION OF PRIVATIZED MILITARY FAMILY HOUSING: LESSONS LEARNED
}

\author{
René Cano, Jr., Lieutenant, United States Navy \\ Submitted in partial fulfillment of the requirements for the degree of \\ MASTER OF BUSINESS ADMINISTRATION \\ from the \\ NAVAL POSTGRADUATE SCHOOL \\ June 2012
}

Author:

René Cano, Jr.

Approved by:

Kenneth J. Euske, Lead Advisor

Becky D. Jones, Support Advisor

William R. Gates, Dean

Graduate School of Business and Public Policy 
THIS PAGE INTENTIONALLY LEFT BLANK 


\title{
AN EVALUATION OF PRIVATIZED MILITARY FAMILY HOUSING LESSONS LEARNED
}

\begin{abstract}
An analysis of previous efforts to privative military housing and of the current privatization initiative revealed that long-term success requires flexibility to manage the private developers' and U.S. government's exposure to various types of risks. The objective of this report is to identify how the Department of Defense has applied the lessons of early privatization efforts to manage risks and to guarantee success of the current Military Housing Privatization Initiative. Reviews of government reports, surveys, presentations, journal articles, and Congressional testimony were used to trace the progression of these privatization programs in order to highlight key lessons learned and provide a holistic perspective of the evolution of the privatization of military housing.
\end{abstract}


THIS PAGE INTENTIONALLY LEFT BLANK 


\section{TABLE OF CONTENTS}

I. INTRODUCTION. .1

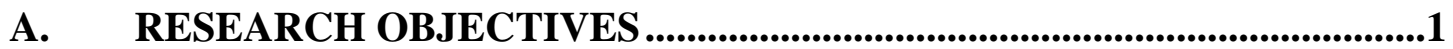

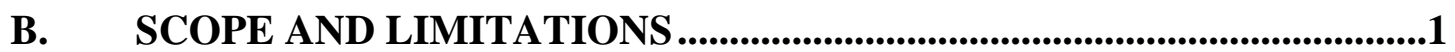

C. METHODOLOGY AND ORGANIZATION OF STUDY ..........................2

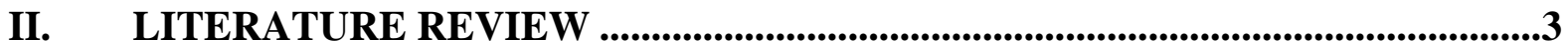

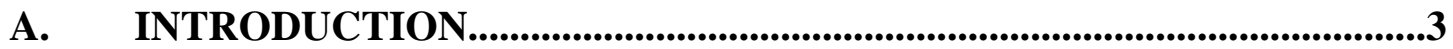

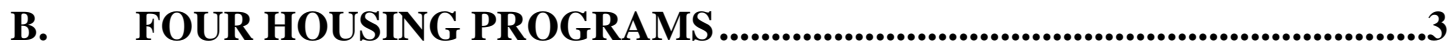

C. THE WHERRY PLAN .................................................................................5

1. Wherry Plan Overview and Procedures .............................................5

2. Wherry Plan Obstacles...................................................................6

a. Wherry Program Comes Under Investigation ...........................6

b. Actions Following the Investigation .......................................7

c. Accusations of Windfall Profits................................................7

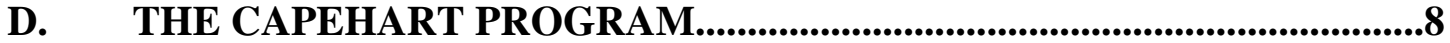

1. Capehart Program Overview and Procedures...................................8

2. Capehart Plan Obstacles .......................................................................9

a. Sponsors Bids Exceed FHA Estimates....................................9

b. High Vacancy Rate at Wherry Housing Leads to DoD Acquisition of Wherry Housing Units..................................10

E. YEARS AFTER THE WHERRY AND CAPEHART PROGRAMS .......11

F. SECTION 801 AND 802 HOUSING PROGRAMS.....................................12

1. Section 801 Program: Build-to-Lease Guarantee ..............................13

2. Section 801 Obstacles.............................................................................14

a. Comparative Cost.....................................................................14

b. Installment-Purchase Not a Viable Option............................15

c. Budget Scoring Rules Change for Leases.............................15

3. Section 802 Program, Rental Guarantee .........................................16

G. CONCLUSION ...................................................................................17

III. MILITARY HOUSING PRIVATIZATION INITIATIVE ...............................19

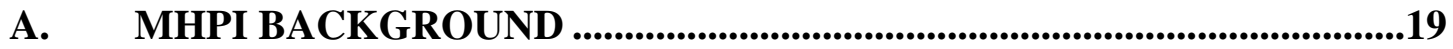

B. THE MHPI PROCESS OVERVIEW ......................................................19

1. MHPI Procedures .........................................................................20

a. Concept Approval ...............................................................20

b. Solicitation Development ....................................................20

c. Proposal Evaluation and Project Award.................................21

d. Oversight and Monitoring ..................................................21

2. MHPI Alternative Authorizations...............................................21

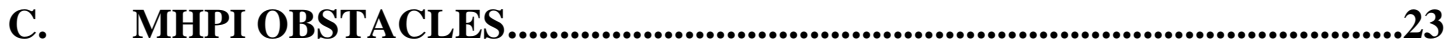

1. Early Delays in Implementing MHPI ..........................................23

2. Requirements Determination Process................................................223

a. Inconsistent Requirements Determination Processes ..........24 
b. Increases in Housing Allowances ...............................................24

c. Differences In Housing Standards............................................25

3. An Integrated Long-Term Strategy ..................................................25

4. Life-Cycle Cost Analysis...........................................................................26

D. CONCLUSION ………..............................................................................29

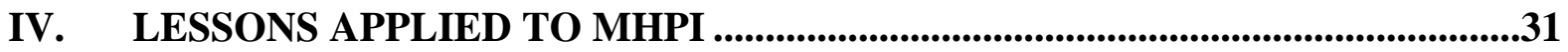

A. IMPORTANCE TO THE ALTERNATIVE AUTHORITIES ....................31

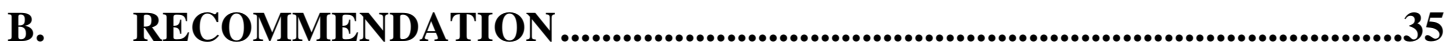

C. CONCLUSION ……...........................................................................................35

APPENDIX. AUTHORITIES IN THE MILITARY HOUSING PRIVATIZATION

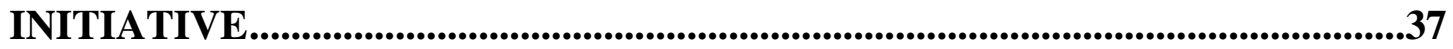

LIST OF REFERENCES..............................................................................................39

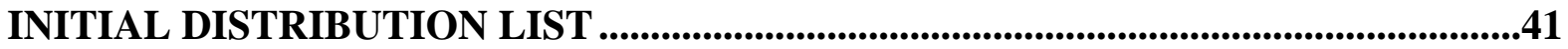




\section{LIST OF FIGURES}

Figure 1. Substandard Living Conditions at Fort Dix, New Jersey, in 1949 (From Life Magazine, March 7, 1949, p. 34).............................................................4

Figure 2. The MHPI Process (From DoD 2006a, 9) .................................................20

Figure 3. DoD Housing Management Manual Policy for Determining Life-Cycle Cost for the Privatization Option (After DoD 2010a)..................................28

Figure 4. Total Project Financial Contributions (From DoD 2012)...........................29

Figure 5. DoD's Progress Towards Adequate Housing (From DoD 2012) ...................30

Figure 6. Total Privatized Units Since MHPI Inception (From DoD 2012) ..................30

Figure 7. $\quad$ Relationships between Risks and Alternate Authorities ...............................33 
THIS PAGE INTENTIONALLY LEFT BLANK 


\section{LIST OF TABLES}

Table 1. Wherry and Capehart Housing Inventory, 1960 (After Peeler et al. 2007, chap. 4, 94)..............................................................................................11

Table 2. Summary of Section 801 and 802 Programs (After Baldwin 1996; 10 U.S.C. §2836) ..................................................................................13

Table 3. Total Number of Units Constructed Under the Four Private Housing Programs (After Baldwin 1996; Defense Science Board 1995) ………............17

Table 4. Alternative Authorizations Ranked by Impact on Budget (After Else 2001)..22 
THIS PAGE INTENTIONALLY LEFT BLANK 


\section{LIST OF ACRONYMS AND ABBREVIATIONS}

$\begin{array}{ll}\text { BAH } & \text { Basic Allowance for Housing } \\ \text { BAQ } & \text { Basic Allowance for Quarters } \\ \text { DoD } & \text { Department of Defense } \\ \text { DUSD(I\&E) } & \text { Deputy Under Secretary of Defense (Installations \& Environment) } \\ \text { FHA } & \text { Federal Housing Administration } \\ \text { FY } & \text { Fiscal Year } \\ \text { GAO } & \text { General Accounting Office } \\ & \text { Government Accountability Office (after July 7, 2004) } \\ \text { MHPI } & \text { Military Housing Privatization Initiative } \\ \text { MilCon } & \text { Military Construction } \\ \text { NPV } & \text { Net Present Value } \\ \text { OMB } & \text { Office of Management and Budget }\end{array}$


THIS PAGE INTENTIONALLY LEFT BLANK

xiv 


\section{ACKNOWLEDGMENTS}

To my wife and best friend, Amy Jo: you have tolerated my many retreats to the

office and excursions to sea. You continue to support me all the way. I love you and cannot thank you enough for all that you do.

To Dr. Kenneth Euske and Professor Becky Jones: Thank you for your infinite patience and encouragement that kept me on the right track. 
THIS PAGE INTENTIONALLY LEFT BLANK 


\section{INTRODUCTION}

Housing philosophy and policy must be rewritten to ensure it is equitable and promotes high morale, readiness, esprit-de-corps and a sense of personal responsibility and community support.

—Defense Science Board Task Force on Quality of Life

For many years, the U.S. military has struggled with ensuring that its service members and their families were provided with adequate military housing. The quantity of available military housing has been restricted by competing budget priorities, and the quality of military housing has often lagged the continuous improvement of privatesector housing standards and amenities. This struggle has led to the slow deterioration of the military's housing stock, with nearly 180,000 inadequate housing units by the mid1990s. As a result, the Department of Defense (DoD) presented Congress with a plan to implement a new, revolutionary approach to solve the housing crisis by allowing the service departments to partner with private organizations to undertake the revitalization of military housing. By using the private sector's expertise and resources, the DoD has been able to eliminate nearly all inadequate housing and successfully privatize family housing projects across the country (U.S. Senate Committee 2012; DoD 2010b).

\section{A. RESEARCH OBJECTIVES}

Privatization experiments have been attempted in the past but did not achieve the same level of success as the current Military Housing Privation Initiative (MHPI) has proven (U.S. Senate Committee 2012). The objective of this report is to identify how the DoD has applied the lessons of early privatization efforts to manage risks and to guarantee success of the current MHPI.

\section{B. SCOPE AND LIMITATIONS}

To identify how the DoD has applied the lessons of early privatization efforts, this project highlights key lessons learned and provides a holistic perspective to the evolution of the privatization of military housing. The project's primary focus is on domestic 
military family housing following the end of World War II. Though the DoD has addressed housing for unaccompanied service members in parallel with efforts to privatize family housing, inclusion of unaccompanied housing in this report would hamper analysis due to the inherent differences of these two types of housing benefits and clientele. In the same regard, this report does not identify or elaborate on specific attributes within each service's acquisition process or execution of housing master plans unless where required to support the project's objectives.

\section{METHODOLOGY AND ORGANIZATION OF STUDY}

Reviews of government reports, surveys, presentations, journal articles, and Congressional testimony were used to trace the progression of the privatization programs. Portions of these documents are included in the tables and figures of this report.

Chapter II provides a background of previous privatization experiments and addresses key issues that led to their demise.

Chapter III shifts to describing the current MHPI process and then explores the significant challenges in achieving the elimination of inadequate housing through privatization. The current state of the MHPI is summarized at the end of the chapter.

Chapter IV presents analysis on the issues identified in early privatization programs and on how these issues were mitigated in the MHPI. 


\section{LITERATURE REVIEW}

Our installations are the home of U.S. combat power-and our installation assets are an inseparable element of the nation's military readiness and wartime effectiveness.

—2007 Defense Installations Strategic Plan

\section{A. INTRODUCTION}

This chapter provides a summary of research conducted on early efforts to privatize military housing following the period after World War II. This literature review provides a perspective on the lessons learned from past privatization attempts, and the political and economic challenges surrounding the DoD's efforts to leverage the private industry resources to provide military family housing in the most efficient and economical means.

As a historian for the U.S. Army Corps of Engineers Office of History, Dr. Baldwin researched and produced the essay, "Four Housing Privatization Programs: A History of the Wherry, Capehart, Section 801 and Section 802 Family Housing Programs in the Army," tracing the creation of four military housing privatization programs employed in the twentieth century. His work supported efforts by the U.S. Army Engineer Strategic Studies Center to present research on the future of military housing for the U.S. Army Chief of Staff (Baldwin 1996). Baldwin documented these early privatization experiments and lessons learned from the end of World War II to the beginning of modern day privatization efforts.

\section{B. FOUR HOUSING PROGRAMS}

The narrative of military family housing begins in the period following the end of the Second World War. Rising tensions between the United States and the Soviet Union required that the U.S. maintain a large peacetime standing army. Though the onset of the Cold War posed many challenges for the armed forces, housing the largest peacetime army with only a small stock of existing family housing quickly became a challenge (Baldwin 1996). 
In the 1940s, before and after the war, permanent construction of new units and maintenance on existing structures had been a low priority. Unfortunately, many service members accepted living in substandard living conditions due to the inadequate housing supply at some bases (Figure 1).

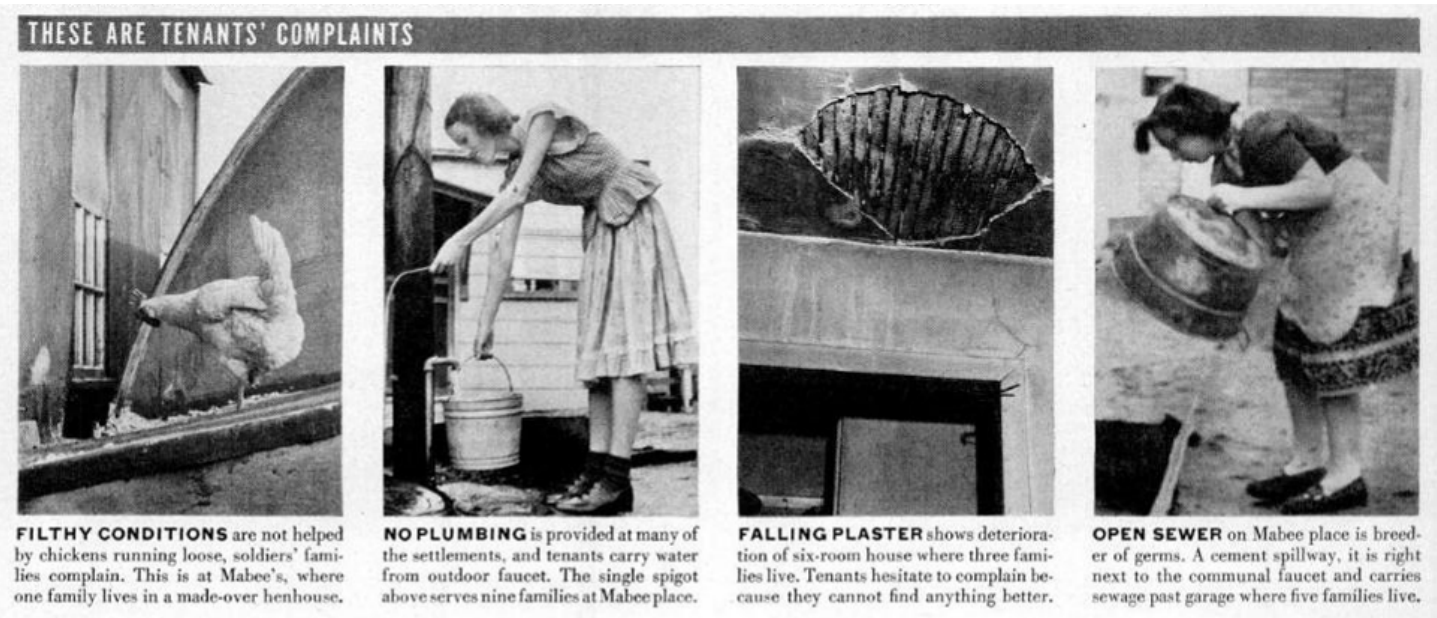

Figure 1. Substandard Living Conditions at Fort Dix, New Jersey, in 1949 (From Life Magazine, March 7, 1949, p. 34)

In 1948, the Secretary of the Army urged base commanders to meet with local businessmen and persuade them to build housing near installations for military families to immediately address this housing problem. These businessmen were reluctant to partner with military commanders to build housing for many reasons (Baldwin 1996). Baldwin notes that the main concern of private investors was that the venture was too risky. For the private investor, the success of the project directly hinged on the number of personnel assigned to an installation, which could fluctuate during the term of the project as military commanders reassigned personnel. Furthermore, investors/developers were entirely dependent on the base staying open during a period of post-war base shutdowns. If a base were to shut down, developers feared that they would be left holding vacant properties (Baldwin 1996). While base commanders attempted to work out these challenges at the local level, Congress took action to solve the military housing shortage. 


\section{THE WHERRY PLAN}

In 1949, Senator Kenneth S. Wherry from Nebraska introduced a bill that provided a solution for the Army's housing shortage. This bill was modeled after the Section 608 programs of the Depression-era Housing Act of 1934, which later provided insurance for housing war workers and veterans returning from war. Senator Wherry's bill allowed developers, termed sponsors, to bid on housing projects deemed necessary by the Secretary of Defense. The service would then charge the developers with the construction, operations, and maintenance of the housing. These projects were built on either private property near installations or inside the installation on land leased from the DoD. The Secretary of Defense was responsible for certifying that an installation's housing needs were justified and that the service had no intentions of closing the base or curtailing its activities (Baldwin 1996).

Senator Wherry's bill was enacted in late 1949, the same year it was introduced. The secretary of defense and the FHA commissioner were authorized to approve mortgages at an average $\$ 8,100$ per unit with a maximum of $\$ 9,000$ for single-family detached units for higher-ranking personnel. Unfortunately, at these prices, rental rates were too expensive and exceeded the Basic Allowance for Quarters (BAQ) ${ }^{1}$ of junior personnel; however, legislators agreed that senior personnel should be steered toward Wherry housing, leaving traditional government quarters to be assigned to lower-ranking personnel. Additionally, Congress had set the maximum mortgage interest rate at 4 percent and maximum mortgage amount to 90 percent of replacement cost. With the mortgage amount being short of the full cost for developing a project, developers would have some incentive to efficiently and economically operate the housing (Baldwin 1996).

\section{Wherry Plan Overview and Procedures}

According to Baldwin (1996), the Federal Housing Administration (FHA) played a key role in privatized military housing under the Wherry plan. First, the FHA provided mortgage insurance to private sponsors in order for them to more easily obtain a loan from a private lender. This insurance was funded from the newly established Military

\footnotetext{
${ }^{1} \mathrm{BAQ}$ is a housing allowance similar to the current Basic Allowance for Housing (BAH).
} 
Housing Insurance Fund supported by insurance premiums paid by the private sponsors. After obtaining mortgage insurance from the FHA, the developer could then solicit a loan from a private lender. The developer would then enter contract to build, operate, and maintain the specified number and type of housing units for the service department. Also, the FHA established rental schedules for the Wherry units that allowed sponsors to make a profit and pay for the cost for operations, maintenance, and debt amortization. The FHA also set standards for housing design, construction, and habitability (Baldwin 1996).

Wherry housing was considered rental housing instead of government quarters since the homes were privately owned. Sponsors were authorized to rent housing to civilians but only after giving priority to service members. Military members who chose to rent could do so using their BAQ (Baldwin 1996).

\section{Wherry Plan Obstacles}

Baldwin (1996) describes how problems were quickly encountered as the program was implemented and the services began to propose new housing projects.

As proposals were submitted and then rejected by the FHA, sponsors started to complain about the process and associated delays. The FHA rejected many of the service's project proposals because the schedules of rent were too low and designs failed to meet FHA standards (Baldwin 1996). The Secretary of Defense temporarily suspended the program and appointed an investigating commission to review delays in the program and the sponsor selection processes (Peeler et al. 2007, chap. 4, 72-73).

\section{a. Wherry Program Comes Under Investigation}

The Department of Defense Housing Commission was charged with conducting this investigation. In addition to the issues with the rejected proposals, the commission found that prospective developers were placing bids equal to the amount of mortgage that they could obtain instead of a bid that included the equity they would place in the project. Under the original Wherry program bill, sponsors were limited to only obtaining a mortgage at 90 percent of the cost of the project and had to provide the remaining 10 percent from other funds. The commission discovered that a developer 
potentially could have built a project solely with the mortgage and could have foregone investing any equity in the project (Baldwin 1996). Baldwin (1996) terms this practice of funding 100 percent of the project with the mortgage as "mortgaging out."

Additionally, the commission determined that delays in the program were due to "cumbersome" procedures related to selection of sponsors and staffing of military field offices (Peeler et al. 2007, chap. 4, 72).

\section{b. Actions Following the Investigation}

In May of 1950, Congress passed legislation to cure some of the problems of the program. To address the problem with project designs not meeting FHA requirements, Congress authorized the services to hire architect-engineer firms to draw up plans and specifications upon which developers would bid vice having the developer present their own design plans which as previously noted, might not meet FHA requirements. To offset the service's cost for hiring these design firms, the winning bidder would reimburse the government for the design fees (Baldwin 1996).

Although the outcome of the investigation did not lead to resolving any of the issues with mortgaging out, the DoD streamlined some of the program's processes by revising the sponsor selection procedures and defining areas of responsibility between all stakeholders: the service secretaries, the FHA, architecture and engineering firms, and sponsors (Peeler et al. 2007, chap. 4, 73).

\section{c. Accusations of Windfall Profits}

According to Baldwin (1996), the issue with sponsors mortgaging out, building their projects for less than the FHA authorized amount, did not sit well with many members of Congress. Congress enacted an "anti-windfall profits" amendment to Title VIII of the National Housing Act in 1953. The amendment required private sponsors to certify that the actual cost of their projects equaled or exceeded the FHAinsured mortgage amount. This cost certification process also had the sponsors repay the difference, or "windfall profits," to their lenders. Though these provisions were unpopular with builders, it did not stop the practice of mortgaging out since it did not 
enforce the 10 percent equity requirement. This amendment only required that the sponsor certify, at a minimum, that the total cost of the project equaled the mortgage amount, potentially sanctioning the practice of mortgaging out since the mortgage only represented 90 percent of the total cost of the project (Baldwin 1996).

In the spring of 1954, Congress enacted a tougher cost certification provision that would end the practice of mortgaging out. Under this new law, builders had to certify that the mortgage was no more than 90 percent of the actual cost of the projects. This provision enforced the requirement for the sponsors to bring 10 percent equity to the project as originally intended (Baldwin 1996). Baldwin (1996) notes that this more stringent anti-windfall profit provision caused many builders to become disinterested and that this change essentially killed the Wherry program. Only a handful of new Wherry projects started after August 1954 (Baldwin 1996).

\section{THE CAPEHART PROGRAM}

As construction firms lost interest in the Wherry program, Congress reconsidered how to address the housing problem in the armed forces. Though the Wherry program quickly relieved housing needs, the increased military activity during the Korean War, in combination with the deterioration of World War II temporary housing, created an overall increase in the services' demand for housing. A new program sponsored by Indiana Senator Homer E. Capehart attempted to correct the short falls of the Wherry program and renew the interest in utilizing private investment to quickly and economically rectify the military housing shortage (Peeler et al. 2007, chap. 4, 83).

\section{Capehart Program Overview and Procedures}

Baldwin (1996) states that the major differences between the Capehart and the Wherry programs were that the maximum unit cost increased from $\$ 9,000$ to $\$ 13,500$, and that private sponsors would only build and not operate family housing units. Capehart housing was only built on government land vice a mix of government lands and privately leased property as with the Wherry program (Peeler et al. 2007, chap. 4, 83). To address the problems of windfall profits as noted during the Department of Defense 
Housing Commission's investigation in 1950, the Capehart legislation was subject to the Renegotiation Act of 1951. This act allowed the government to recover excess profits from private benefactors (Baldwin 1996).

The role of the FHA in the Capehart program was to provide mortgage insurance to private sponsors and estimate replacement cost of projects as in the Wherry program. The FHA was authorized to require the DoD to guarantee the mortgage insurance fund against loss if the agency disagreed with the Secretary of Defense's determination of the need to build housing. This requirement provided incentive for the DoD to be judicious in adhering to FHA recommendations (Baldwin 1996).

Upon winning a bid, the sponsor formed a new company for each project, and then obtained mortgage insurance (for 100 percent of the bid) from the FHA and a mortgage from a private lender (for 25-years at a rate limited to 4 percent at average cost of $\$ 13,500$ per unit). The corporation would then reimburse the service for the design cost. At the completion of construction, the corporation was turned over to the service (Baldwin 1996).

The Secretary of Defense certified the need for housing at an installation to initiate the project (Baldwin 1996). The service departments hired architect-engineering firms to design projects put up for bid. Once a project was completed and turned over with the mortgage to the service, the mortgage would be paid down with service members' BAQ, and the project would be operated and maintained with appropriated funds (Baldwin 1996).

\section{Capehart Plan Obstacles}

Like the Wherry program, the Capehart program had problems early in its implementation.

\section{a. Sponsors Bids Exceed FHA Estimates}

Baldwin (1996) discusses that many project bids exceeded the independently developed FHA replacement cost estimates. Like the Wherry program, the FHA would provide mortgage insurance funded by the program's participants. In a few 
cases, the FHA's replacement cost estimates were below all the bids on a project. For one project, the FHA was able to revise its estimate since the difference between the lowest bid and the FHA estimate was small, and they eventually allowed the project to move forward. In another instance, the different between the FHA estimate and the lowest bid was so large that the FHA was unwilling to make substantial changes to its estimate, thereby forcing the Army to cancel the project. To solve these issues, Congress enacted the Housing Act of 1956, which increased the mortgage amount from $\$ 13,500$ to \$16,500. After its passage, all bids were below the FHA estimate (Baldwin 1996).

\section{b. High Vacancy Rate at Wherry Housing Leads to DoD Acquisition of Wherry Housing Units}

During the hearings leading up to the Capehart legislation, Wherry housing sponsors began to voice concerns about the ability of their housing projects to compete with the newer and larger Capehart housing (Peeler et al. 2007, chap. 4, 91). Baldwin (1996) describes that service members preferred the larger and newer Capehart housing and that installation commanders also preferred Capehart housing since they had authority over the projects once they were turned over to the government when construction was completed.

Wherry sponsors expressed that a vacancy rate higher than 5 percent would be unprofitable and that vacancy rates would increase as more Capehart housing came online. Eventually, 17 percent of all Wherry projects had vacancy rates of more than 5 percent by 1956 (Baldwin 1996).

Higher vacancies were further exacerbated by taxes levied by local governments. Wherry sponsors experienced this setback in 1956 when the Supreme Court ruled that local governments could legally tax Wherry projects. With this increase in cost, owners of Wherry properties applied to the FHA for authority to increase rental rates in compensation of the increased tax burden. ${ }^{2}$ Unfortunately for Wherry sponsors, these local taxes and the subsequent increase in rental rates were not enough to make Wherry housing more attractive, thereby further increasing vacancy rates (Baldwin 1996).

\footnotetext{
2 Rental schedules had not originally accounted for any allowance for local taxes (Baldwin 1998).
} 
In order to ease the problems with high vacancies in Wherry housing, the Housing Act of 1955 was passed to allow the Secretary of Defense to acquire Wherry units from the private sponsors at a fee equal to an FHA calculated replacement cost (less depreciation) formula which happened to be less than the fair market value of the units. Once additional legislation was passed in 1957 to provide sponsors with more favorable compensations, the DoD immediately began to acquire Wherry units, and by 1959 had acquired 70 percent of all Wherry units. The newly acquired Wherry housing units were eventually improved to Capehart specifications, which were generally larger and had more amenities (Baldwin 1996).

The Wherry and Capehart housing programs helped the armed forces quickly meet their family housing demand despite some short comings. Though Wherry sponsors became disappointed as the program progressed, they had been able to make a profit on the construction which in some cases exceeded Congressional expectations. Also, the mortgage insurance premiums collected by the FHA were able to cover the default of 23 projects, which was an improvement over the performance of the Section 608 program where defaults were more than three times as large (Baldwin 1996). The end results of both Wherry and Capehart programs are provided in Table 1.

\begin{tabular}{|l|r|r|r|r|}
\hline & \multicolumn{1}{|c|}{ Navy } & \multicolumn{1}{c|}{ Air Force } & \multicolumn{1}{c|}{ Army } & \multicolumn{1}{c|}{ Total } \\
\hline $\begin{array}{l}\text { Wherry } \\
\text { Units }\end{array}$ & 24,366 & 36,812 & 22,249 & 83,427 \\
\hline $\begin{array}{l}\text { Capehart } \\
\text { Units }\end{array}$ & 19,806 & 59,142 & 36,351 & 115,299 \\
\hline
\end{tabular}

Table 1. Wherry and Capehart Housing Inventory, 1960 (After Peeler et al. 2007, chap. 4, 94)

\section{E. YEARS AFTER THE WHERRY AND CAPEHART PROGRAMS}

Even though there were efforts to privatize military family housing in the postwar period with the Wherry and Capehart programs, the armed services supplemented privatization efforts with the construction of family housing using appropriated funds. Military construction funds were used in high cost and isolated areas, such as in Alaska, 
where the Wherry and Capehart programs could not be implemented (Peeler et al. 2007, chap. 5, 105). Baldwin (1996) reports that during the 1960s and 1970s military family housing privatization programs fell out of political favor with Congress, and the DoD returned to building housing solely with appropriated funds. During the Vietnam War, expanding the military's family housing stock was a low priority within the DoD. The budget priorities of the Carter Administration did not support increasing the level of housing construction, even though the proportion of married enlisted members had been on the rise since the end of World War II (Baldwin 1996).

Nearly three decades after the Wherry plan of the 1950s, military housing needed to be revitalized, and in 1983, the Reagan Administration looked to the private sector to improve the military housing supply (Baldwin 1996).

\section{F. SECTION 801 AND 802 HOUSING PROGRAMS}

The Military Construction Authorization Act was signed by President Reagan in October of 1983 and contained two sections pertaining to military housing: 1) Section 801, which established the Military Family Housing Program and 2) Section 802, which established the Military Housing Rental Guarantee Program. These programs were initially established as pilot programs which would require renewal every two years. Congress eventually passed legislation to make these programs permanent in 1991, even though the DoD had phased out use of these programs in the 1990s (Baldwin 1996). Table 2 summarizes the major attributes of these two programs. 


\begin{tabular}{|c|c|}
\hline Section 801 & Section 802 \\
\hline $\begin{array}{l}\text { Projects constructed on private or } \\
\text { public lands. }\end{array}$ & $\begin{array}{l}\text { Projects constructed on private or } \\
\text { public lands. }\end{array}$ \\
\hline $\begin{array}{l}\text { Units are rent free to service } \\
\text { members. They do not receive } \\
\text { BAQ. }\end{array}$ & $\begin{array}{l}\text { - Service members pay rent using } \\
\text { BAQ. Rental rates cannot be more } \\
\text { than comparable rental units in the } \\
\text { same area. }\end{array}$ \\
\hline $\begin{array}{l}\text { - Government lease may not exceed } \\
20 \text { years after completion of } \\
\text { construction. }\end{array}$ & $\begin{array}{l}\text { - Rental guarantee is limited to a 15- } \\
\text { year maximum (25 years after } \\
\text { FY87) and is not renewable. }\end{array}$ \\
\hline $\begin{array}{l}\text { - Housing built to military } \\
\text { specifications. }\end{array}$ & $\begin{array}{l}\text { Housing built to military } \\
\text { specifications or local codes as } \\
\text { approved by the service secretary. }\end{array}$ \\
\hline
\end{tabular}

Table 2. Summary of Section 801 and 802 Programs (After Baldwin 1996; 10 U.S.C. §2836)

\section{Section 801 Program: Build-to-Lease Guarantee}

The purpose of the Section 801 program was to increase the military housing supply by encouraging private developers to build new properties for lease to the government. This program allowed developers to bid and enter contract to build new housing either on DoD installations or nearby on private property. Once these projects were completed, the program allowed the DoD to lease this housing from the private developer for a period of twenty years (GAO 1986, 7).

For housing constructed on an installation, there were two phases written into these contracts called “in-lease” and “out-lease” periods. During the in-lease phase, the DoD would lease the housing from the developer at a fixed rental rate (or at a variable rate based on the Consumer Price Index) regardless of occupancy level. After a predetermined period of time, the in-lease phase expired, and the rental burden shifted to the developer. During out-lease phase, the developer would pay the DoD to rent the land on the installation and have the option to rent units to the general public to meet gaps in occupancy. Once the lease was over, the program required the developer to turn over the land back to the DoD in its original condition (Inspector General 2008, 2). 


\section{Section 801 Obstacles}

As with the Capehart and Wherry housing programs thirty years before, the DoD faced hurdles in continually proving the merits of the program to Congress and providing incentives for developers to participate in the program (Baldwin 1996).

\section{a. Comparative Cost}

The act authorizing the Section 801 and 802 programs required that the DoD demonstrate to Congress that a leasing project was more economical than other methods providing the same housing. The DoD used the cost for building housing with appropriated funds as the ceiling cost for the leasing project (Baldwin 1996).

In a 1986 study, the General Accounting Office (GAO) expressed reservations about the DoD's implementation of the analysis of alternatives requirement. The GAO reported that the DoD did not use an adequate basis for determining costeffectiveness in comparing contracts based on a cost versus quality ratio. Using the costquality comparison basis encouraged bidders to offer the highest quality within the cost ceiling, which the GAO investigated and reported to be within 95 and 100 percent of the maximum allowable cost. As a result, the government would have no assurance that housing is obtained for the lowest cost (GAO 1986, 11). Additionally, members of Congress did not believe that leasing was cheaper and insisted that the DoD show at least a 5 percent saving when compared to using appropriated funds to build housing (Baldwin 1996).

With the pressure of confronting a military housing deficit, Congressional appropriation committees demanded the DoD develop a five-year plan to meet the housing demand and extended the Section 801 program for two years. In 1987 as leasing costs were driven down, the DoD produced a plan that required 60 percent of new housing be built with appropriated funds and 40 percent leased with the Section 801 plan. Congressional leaders were still concerned that Section 801 housing was overpriced and that after 20 years of lease payments, the government had nothing to show for these outlays (Baldwin 1996). 


\section{b. Installment-Purchase Not a Viable Option}

Starting in 1988, members of Congress requested the DoD to submit proposed legislation for an installment-purchase program similar to the Capehart program. Members of Congress preferred an installment-purchase program over a leasing program because the government would own the housing once it was paid off (Baldwin 1996). An installment-purchase program, such as the Capehart program of the 1950s (where government took ownership of the housing and mortgage once construction was completed), would give the government more control over the project and would provide the government a real estate asset at the end of the term (Twiss and Martin 1998, 53).

DoD officials argued that an installment-purchase program was not a viable option due to budget scoring rules (Twiss and Martin 1998, 53). Installmentpurchase programs had not been used since the 1950s when Congress implemented a full funding policy for DoD procurement (O’Rourke and Daggett 2007, 1). This policy was designed to allow Congress the ability to exercise more oversight and to better understand total procurement cost in fulfilling its key financial oversight role. Full funding for procurement programs required that the DoD budget for the entire cost of the project in the year that it is procured (O’Rourke and Daggett 2007, 2). Even though installment-purchase programs, such as the Capehart program, were attractive alternatives, leasing allowed the DoD to budget one year's worth of housing at a time vice budgeting for 20 years of costs in one year (Baldwin 1996).

\section{c. $\quad$ Budget Scoring Rules Change for Leases}

In 1990, Office of Budget and Management (OMB) changed how longterm leases, like the Section 801, would be scored in annual budgets. Like scoring installment-purchases, budgets would now more accurately reflect the total obligated cost of a 20-year lease. Specifically, leases would be scored for the total legal obligation in the year that the lease is first incurred instead of being scored on an annual basis. These new rules typically made the total capital cost of a project, plus the financing premium, greater than an outright purchase of housing with appropriated funds. This change to scoring leases made the Section 801 housing projects so unattractive that the DoD effectively 
abandoned the program (Defense Science Board 1995, 57-58). At the end of FY91, the DoD announced that no future request would be made for projects under the Section 801 and 802 programs (Baldwin 1996).

\section{Section 802 Program, Rental Guarantee}

The DoD used the Section 802 program to encourage private developers to build rental units for direct lease to service members by guaranteeing an occupancy level of no less than 97 percent. Private developers were allowed to lease housing to civilians but were required to give priority consideration to service members (GAO 1986, 7). The terms of this guarantee were originally set to be 15 years and were then extended to 25 years by Congress in 1986 to provide more incentive to private developers (Baldwin 1996).

The cost of the Section 802 program was centered on the service members' ability to pay instead of the cost to build and maintain as with the Section 801 program (Baldwin 1996). The rental rate the service member would pay the developer was the sum of the following: BAQ, plus Variable Housing Allowance, plus 15 percent out of pocket expense from the service member, less the estimated cost of utilities (Defense Science Board 1995, 62).

Baldwin (1996) explains that this program was not successful because there was not enough incentive to offset the risk for developers to participate. The two issues that presented risks for developers were low ceiling costs and the fact that a major portion of the rent was frozen over the term of the contract (Baldwin 1996).

First, to offset the low ceiling cost, the DoD worked with Congress to modify the program to entice developers by only building Section 802 on government land and providing utilities from the base to offset those costs, having developers renovate existing housing, and by lengthening the rental period from 15 to 25 years (Baldwin 1996).

Second, given that a majority of the rent was frozen, developers would be exposed to the risk of inflation. The rent consisted of two portions: (1) shelter rent, which was fixed, and (2) an adjustable maintenance rate. Because of this exposure to inflation, 
developers experienced difficulty in obtaining financing (GAO 1986, 19). Not until 1990 did a service come forward to seek approval for a Section 802 housing project. The Army, which was in charge of all housing in Hawaii, announced the first Section 802 project, 276 units, to be completed on the Kaneohe Bay Marine Corps Base (Baldwin 1996). This project was the only Section 802 project completed (Defense Science Board 1995, 62).

\section{G. CONCLUSION}

Baldwin (1996) recaps that the DoD had demonstrated that three privatization methods proved to be lasting and appropriate for providing military family housing under favorable conditions: 1) rental guarantees, 2) installment-purchases, and 3) leasing. Rental guarantees had some problems domestically in the Section 802 program, but proved to be beneficial in the Overseas Rental Guarantee program. ${ }^{3}$ Secondly, the installment-purchase method allowed developers to build housing with mortgages insured by the federal government, as in the Capehart plan, and then the service would take over the mortgage and amortize them with appropriated funds once construction was completed. Lastly, the leasing method did not provide much benefit over MilCon alternatives after changes to budget scoring made this program unfavorable (Baldwin 1996). Table 3 shows the results of homes produced by the four privatization programs.

\begin{tabular}{|l|r|}
\hline Program & Total (units) \\
\hline Wherry & 83,427 \\
\hline Capehart & 115,299 \\
\hline Section 801 & 11,100 \\
\hline Section 802 & 273 \\
\hline
\end{tabular}

Table 3. Total Number of Units Constructed Under the Four Private Housing Programs (After Baldwin 1996; Defense Science Board 1995)

\footnotetext{
${ }^{3}$ In the Overseas Rental Guarantee program, established in 1952, the DoD would work with private developers to provide housing. The DoD would commit to certain levels of occupancy for a fixed period of time similar to the Section 802 program (Baldwin 1996).
} 
THIS PAGE INTENTIONALLY LEFT BLANK 


\section{MILITARY HOUSING PRIVATIZATION INITIATIVE}

We must demonstrate to our men and women in service that their qualityof-life needs will be taken care of so that they can dedicate their full attention to the mission. When military members worry unduly about personal finances and whether their families are properly cared for, morale and efficiency decline with corresponding effects on retention and readiness.

—Major General R. Dean Tice

\section{A. MHPI BACKGROUND}

In 1998, the DoD reported to Congress that approximately 200,000 of existing military family housing units needed to be renovated or replaced due to age or inadequate maintenance. The DoD proposed that the private sector's investment capital and expertise were needed to provide new, higher quality housing in the quickest and most efficient manner over a ten-year period (GAO 1998, 3).

At the DoD's request, Congress enacted the Military Housing Privatization Initiative (MHPI) as part of the FY96 National Defense Authorization Act, creating new authorities in 10 U.S.C. for privatization for military housing (GAO 1998, 2). The MHPI, initially authorized for five years as a pilot program, was made permanent in 2004 (DoD 2006a, 4). The new provisions in 10 U.S.C. granted DoD the authority to 1) provide direct loans and loan guarantees to private entities, 2) lease existing property and facilities to private entities, and 3) allow developers to design and build military housing comparable to housing in the local communities (GAO 1998, 2-3). Unlike privatization programs discussed in the previous chapter, the MHPI gave the DoD flexibility to act like a private enterprise by taking advantage of local market conditions and by tailoring the financial resources for each development project (Else 2001, 4).

\section{B. THE MHPI PROCESS OVERVIEW}

As outlined in the DoD Housing Management Manual (2010a), the process of using privatization to build new housing is a multi-step process. Figure 2 depicts an overview of how the procurement process flows for a typical project. 


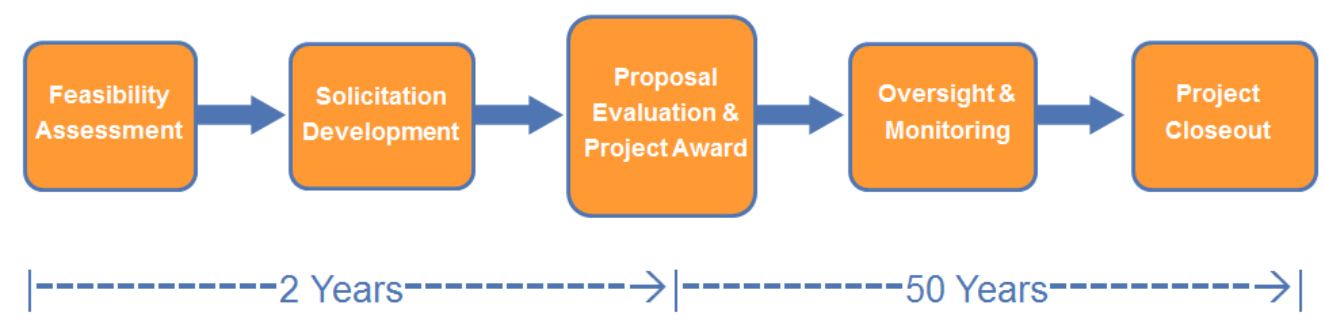

Figure 2. The MHPI Process (From DoD 2006a, 9)

\section{MHPI Procedures}

Governing procedures for the MHPI process are outlined in 10 U.S.C. and in the DoD Housing Management Manual (4164.63-M). The Office of the Secretary of Defense provides overall oversight and serves as an approval authority for each of the milestones. The service departments are responsible for procurement procedures and execution of the project. Congressional notification is required before solicitation is issued to the public and prior to awarding the project (Else 2001, 8)

\section{a. Concept Approval}

The first step in the process is concept approval, also known as the feasibility assessment. A feasibility study is conducted by the service to determine whether the required housing will be newly constructed or renovated from existing properties. The service departments examine project concepts and conduct cost-benefit analysis between MHPI authorities and traditional MilCon alternatives (Else 2001, 8). The services are responsible for covering any cost for project development and consultant expenses during this phase. The services then present concept briefs to the Deputy Under Secretary of Defense (Installations \& Environment) (DUSD(I\&E)). These briefs demonstrate validation of the requirements, provide financial justification, and address any issues specific to the project (DoD 2010a, 34).

\section{b. Solicitation Development}

Once the DUSD(I\&E) approves the project concept, the service secretary is authorized to notify Congress of the service's intention to solicit proposals for the 
project (DoD 2010a, 34). This notification to Congress is required by $§ 2884$ of 10 U.S.C. Proposals are then reviewed and approved by the DUSD(I\&E), and a solicitation notice is issued to the construction industry (Else 2001, 6). After a thirty-day wait period (sixty days for limited loan guarantees), the service issues requests for proposals and commences the acquisitions process (DoD 2010a, 34).

\section{c. Proposal Evaluation and Project Award}

After all proposals are reviewed, the service presents, an economic analysis, a scoring report, and other project documentation to the DUSD(I\&E) for source selection approval. The DUSD(I\&E) then submits the scoring report to the Office of Management and Budget (OMB) for approval (DoD 2010a, 34). Congressional notification is required before the service awards the contract in accordance with $\S 2884$ of 10 U.S.C.

\section{d. Oversight and Monitoring}

The final step is for the applicable service to execute and monitor the project and provide DUSD(I\&E) with semi-annual status reports on project completion and financial health (DoD 2010a, 35). Additionally, the Secretary of Defense is required to provide an annual report detailing the fiscal expenditure and receipts from DoD housing accounts, ${ }^{4}$ status of activities and acquisitions for each of the services, and other items of interest to the appropriate Congressional committees (10 U.S.C., §2883-§2884).

\section{MHPI Alternative Authorizations}

The MHPI alternative authorizations outlined in 10 U.S.C. allow the services to scale a project's impact on the budget through various levels of budget scoring. For example, transferring ownership of government assets (e.g., land or housing units) to a developer is scored at zero percent which leads to no impact on the budget. On the other end of the spectrum, use of the build-to-lease authority has a high impact on the budget since the net present value (NPV) of all lease payments would be scored in the first year

\footnotetext{
4 These accounts were established to hold appropriated funds, money received from conveyance of government property, and other income derived from the MHPI financial authorities (10 U.S.C. §2883).
} 
at 100 percent. Overall, the DoD aimed to minimize outlays in the near term by soliciting the private sector to invest at a rate of at least $\$ 3$ for each dollar the government invested in new construction and renovations (GAO 1998, 3). Table 4 describes and ranks the alternative authorities from lowest to highest impact on the budget.

\begin{tabular}{|c|c|c|c|}
\hline Authority & Description & Benefit & Budget Scoring \\
\hline $\begin{array}{l}\text { Conveyance } \\
\text { or Lease of } \\
\text { Land or Units }\end{array}$ & $\begin{array}{l}\text { Transfer of } \\
\text { ownership }\end{array}$ & $\begin{array}{l}\text { Secure private } \\
\text { financing, } \\
\text { immediate cash } \\
\text { flow }\end{array}$ & $\begin{array}{l}\text { None - } 0 \% \text { of land } \\
\text { value }\end{array}$ \\
\hline $\begin{array}{l}\text { Unit Size \& } \\
\text { Type }\end{array}$ & $\begin{array}{l}\text { Build to local } \\
\text { codes }\end{array}$ & $\begin{array}{l}\text { locally } \\
\text { compatible, } \\
\text { cost-effective } \\
\text { construction }\end{array}$ & None \\
\hline $\begin{array}{l}\text { Ancillary } \\
\text { Support } \\
\text { Facilities }\end{array}$ & $\begin{array}{l}\text { Permit } \\
\text { supporting } \\
\text { amenities }\end{array}$ & $\begin{array}{l}\text { Enhance project } \\
\text { attractiveness }\end{array}$ & None \\
\hline $\begin{array}{l}\text { Payment by } \\
\text { Allotment }\end{array}$ & $\begin{array}{l}\text { Guaranteed cash } \\
\text { stream }\end{array}$ & $\begin{array}{l}\text { Minimize rent } \\
\text { payment } \\
\text { uncertainty }\end{array}$ & None \\
\hline $\begin{array}{l}\text { Loan } \\
\text { Guarantees }\end{array}$ & $\begin{array}{l}\text { Guarantee of } \\
\text { private sector } \\
\text { loan }\end{array}$ & $\begin{array}{l}\text { Lower interest } \\
\text { rate, ensure } \\
\text { financing }\end{array}$ & $\begin{array}{l}\text { Low }-4 \%-7 \% \text { of } \\
\text { loan amount }\end{array}$ \\
\hline Direct Loan & $\begin{array}{l}\text { Direct loan to } \\
\text { contractor }\end{array}$ & $\begin{array}{l}\text { Below-market } \\
\text { financing }\end{array}$ & $\begin{array}{l}\text { Moderate }-30 \%- \\
70 \% \text { of loan } \\
\text { amount }\end{array}$ \\
\hline $\begin{array}{l}\text { Differential } \\
\text { Lease } \\
\text { Payments } \\
(D L P)\end{array}$ & $\begin{array}{l}\text { Pay difference } \\
\text { between BAH } \\
\text { and market rents }\end{array}$ & $\begin{array}{l}\text { Leverages } \\
\text { private } \\
\text { financing }\end{array}$ & $\begin{array}{l}\text { Moderate to High - } \\
\text { NPV of DLP over } \\
\text { contract life }\end{array}$ \\
\hline $\begin{array}{l}\text { Investment } \\
\text { (Joint } \\
\text { Venture) }\end{array}$ & $\begin{array}{l}\text { Equity } \\
\text { investment }\end{array}$ & $\begin{array}{l}\text { Partnership } \\
\text { interest }\end{array}$ & $\begin{array}{l}\text { Moderate to High - } \\
100 \% \text { of cash } \\
\text { equity }\end{array}$ \\
\hline $\begin{array}{l}\text { Interim } \\
\text { Leases }\end{array}$ & $\begin{array}{l}\text { Government } \\
\text { lease of other } \\
\text { units until project } \\
\text { conveyed }\end{array}$ & $\begin{array}{l}\text { Enables } \\
\text { immediate } \\
\text { occupancy }\end{array}$ & $\begin{array}{l}\text { Moderate to High - } \\
\text { NPV of lease } \\
\text { payments during } \\
\text { interim }\end{array}$ \\
\hline $\begin{array}{l}\text { Assignment of } \\
\text { Members } \\
\text { (Tenant } \\
\text { Guarantee) }\end{array}$ & $\begin{array}{l}\text { Members } \\
\text { assigned housing } \\
\text { in project }\end{array}$ & $\begin{array}{l}\text { Forces above } \\
\text { market } \\
\text { occupancy rate }\end{array}$ & $\begin{array}{l}\text { High - NPV of } \\
\text { BAH }\end{array}$ \\
\hline $\begin{array}{l}\text { Build to } \\
\text { Lease }\end{array}$ & $\begin{array}{l}\text { Contract } \\
\text { construction, } \\
\text { lease units }\end{array}$ & $\begin{array}{l}\text { Central } \\
\text { payment by } \\
\text { DOD (801-like) }\end{array}$ & $\begin{array}{l}\text { High - NPV lease } \\
\text { payments }\end{array}$ \\
\hline $\begin{array}{l}\text { Rental } \\
\text { Guarantee }\end{array}$ & $\begin{array}{l}\text { Guarantee of } \\
\text { occupancy or } \\
\text { rental income }\end{array}$ & $\begin{array}{l}\text { Enhances } \\
\text { financing } \\
\text { (802-like) }\end{array}$ & $\begin{array}{l}\text { High - NPV rental } \\
\text { payments }\end{array}$ \\
\hline
\end{tabular}

Table 4. Alternative Authorizations Ranked by Impact on Budget (After Else 2001) 


\section{MHPI OBSTACLES}

\section{Early Delays in Implementing MHPI}

The promise to provide housing quicker and cheaper was met with challenges at the start of the program. Within the first two years, only one project at Lackland Air Force Base for 420 new units was close to contract signing (GAO 1998, 22-23). This delay was due to legal, financial, contractual, and budgetary issues in executing the new program. Legal issues had to be addressed in areas of property and acquisition, and new protocols and procedures had to be developed for contracting. Furthermore, the DoD and the OMB had to compromise on how each of the various alternative authorities would be scored. A written agreement was eventually developed for the first twenty projects, pending a review of the agreement for follow-on projects (GAO 1998, 22-23). Because of these delays, the DoD extended the original timeline for meeting its ten-year housing goal by four more years to FY10 (GAO 1998, 4).

As evidenced by several GAO reports (i.e., 1998, 2000, 2001, 2002, 2004, and 2006) to Congress and the DoD, members of Congress were concerned about the DoD requirements determination process, cost analysis, and overall lack of a department-wide long-term strategy.

\section{Requirements Determination Process}

First, some legislators were concerned that the government might be procuring more housing than was required. They were skeptical that the DoD had sufficient assurance that budget submissions correctly addressed actual family housing needs. The GAO $(1996,5)$ found that the services underestimated the private sector's ability to meet military family housing needs and that the methodologies of the services resulted in a self-perpetuating requirement for government housing. In 1997, a review by the DoD's Inspector General revealed that the DoD needed to develop standard processes and procedures for determining family housing requirements (GAO 1998, 33). Overall, the DoD's requirements development process was complicated by using inconsistent methods, increasing housing allowances, and having different housing standards between housing on-base and in the community (GAO 2002). 


\section{a. Inconsistent Requirements Determination Processes}

Contrary to DoD policy, the requirements determination process did not primarily rely on private sector housing first. The DoD's policy to primarily rely on private sector housing was established to be the most economical form of privatization with an average annual government savings of \$4,957 FY95\$ per household. These savings were gained from the service member bearing more out-of-pocket housing expenses, less contributions for education economic impact aid, 5 and no construction, operations, and maintenance costs (GAO 1998, 32-33). Reliance on private sector housing first also provided the services with short-term flexibility by avoiding long-term commitments with MilCon dollars and by avoiding contractual obligations to develop new housing with a risk of military base closures (GAO 1998, 34).

The analysis for required housing often overestimated the housing needed because the department's methods did not properly account for private sector housing (GAO 2002, 8). For example, the services' market analysis sometimes matched the housing need to existing government units rather than first assessing the community's ability to meet the requirements first and then determining additional government housing required to cover the difference. The GAO assessed that this method could possibly lead to the DoD improperly investing dollars to maintain and renovate existing government units which could be retired once they fulfilled their useful life (GAO 2002, 8). In another example, some services required a minimum number of government units even if the community could meet the housing demand or underestimated the number of available vacant units in the community, thereby inflating the number of required units (GAO 2002, 8).

\section{b. Increases in Housing Allowances}

Second, the GAO (2002) assessed that a separate initiative to increase BAH and reduce military members' housing out-of-pocket cost to zero by 2005 had a significant impact on the MHPI requirements determination. As BAH increases, so would

\footnotetext{
5 This aid was compensation paid to local governments for educating military dependents since the government did not pay local taxes for government-owned housing (GAO 1996).
} 
the amount of available housing increase for a given allowance rate, thereby reducing number of government units required for an installation. Also, private investors may see a business opportunity to independently develop housing near military installations to profit from the increased rates.

Altogether, when military members are given a choice between civilian housing and housing on an installation, all costs being equal, studies (e.g., 1999 DoD Survey of Active Duty Personnel and 1999 RAND survey) have shown that members prefer to live in civilian housing (GAO 2002, 9-10). With the increase in BAH rates, the GAO assessed that less housing would be required across the DoD, and the DoD should factor this reduction into their requirements determination process.

\section{c. Differences In Housing Standards}

Lastly, different housing standards for family size inflated the need for military housing. When determining military housing requirements, the DoD used family size as a factor for housing size. This entitled larger military families to houses larger than they may be able to afford in the private community. Comparisons between vacant housing available in the community and military housing required were difficult because housing allowances were the same independent of family size (GAO 2002, 10-11).

Service members would have an incentive to reduce out-of-pocket cost by choosing to live on base where they are entitled to a larger home than they could afford in the local community. This disparity in standards for family size increased the demand for government housing and lowered reliance on the community for housing which was also contrary to DoD's policy of using housing surrounding the installation first (GAO 2002, 10-11).

\section{An Integrated Long-Term Strategy}

According to analysis conducted by the GAO in 2000, the DoD had not developed an overall housing strategy that integrated all resources to address the housing need. A congressional committee directed the DoD to better coordinate the use of housing options, such as housing allowances and military construction, through an integrated 
strategy as the department moved forward with the privatization initiative (GAO 2000, 78). As of 2000, the DoD made some progress in coordinating housing initiatives through the Installations Policy Board, which reviewed and coordinated among various DoD offices on matters of housing, allowances, and member quality of life issues, but did not yet formalize the integrated housing strategy (GAO 2000, 42).

The interdependency between privatization efforts and increasing military housing allowance rates highlights the challenges in coordinating programs across the DoD. An increase in BAH rates may cause demand for on-base housing to go down since military families have shown that they would prefer civilian housing more over on-base housing as BAH rates increase (Buddin et al. 1999, 94). For military privatized housing, an increase in allowance rates would result in a corresponding increase in rental rates to the developer, which could then result in large, unexpected profits. On the other hand, lowering of allowance rates may result in the developer cutting corners on operations and maintenance (GAO 2000, 71).

\section{Life-Cycle Cost Analysis}

In the early years of the MHPI, the DoD was slow in developing consistent methods for determining the project life-cycle cost across all the services. Though cost analysis already had been completed and privatization projects awarded, members of Congress questioned whether the DoD could consistently determine which projects to approve in the government's best interest.

The services compared cost of privatization against the cost of military construction to decide whether a proposed privatization project should be approved for solicitation. In a 2000 GAO report, the GAO found that after reviewing the life-cycle cost analysis for twelve projects, there were inconsistencies, inaccuracies, or lack of support for some assumptions and estimates (GAO 2000, 34):

- Seven analyses did not consider costs for project planning and design;

- Three analyses did not consider the value of government property conveyed to the developers; 
- Two analyses included the value of conveyed property but did not provide supporting documentation for the estimates used;

- Six analyses did not include costs for monitoring the privatization contract;

- Two analyses did not use the correct Office of Management and Budget discount rate to adjust for the time value of money;

- No analyses were performed for two projects.

The GAO proved that the cost analysis prepared by the services showed modest savings from utilizing privatization over military construction. In the housing projects surveyed in the 2000 study, the service's cost analysis estimated that the government would save approximately 12 percent by using privatization instead of military construction. After correcting for cost estimation discrepancies, the GAO estimated that privatization should cost the government about 11 percent less than military construction for the projects assessed (GAO 2000, 36). The DoD agreed that improvements were needed in cost estimation and had previously issued draft guidance in response to a 1998 GAO report, but the DoD still had yet to finalize the report in 2000 (GAO 2000, 63).

The GAO also cautioned that with the modest savings gained by privatization, further increases in housing allowances could make privatization more costly than housing built with military construction funds. The DoD did not agree with this assessment. In response to this report, the Deputy Under Secretary (Installations) stated that an increase in allowances would reduce life-cycle costs since projects would be more "financially viable" and reduce the need for upfront government financial contributions (GAO 2000, 64). The DoD planned to include financial mechanisms ${ }^{6}$ to ensure that lifecycle cost did not increase with an increase in allowances (GAO 2000, 64).

Overall, the GAO assessed that privatization had a relatively low effect on the total cost to the government and merely shifted cost from military construction and operations and maintenance accounts to military personnel accounts in the form of housing allowances (GAO 2000, 37).

\footnotetext{
${ }^{6}$ For example, reinvestment accounts, revenue sharing accounts and increased rents where government property is leased (GAO 2000, 64).
} 
By 2002, the DoD had updated life-cycle cost estimation policies, but the GAO identified areas to further improve to prevent privatization from appearing more favorable than justified. The GAO reported that life-cycle cost estimates would be more reliable by including the cost incurred to oversee project contracts and by using conventional apartment operations and maintenance data instead of federally assisted apartment data (GAO 2002, 15). After recalculating life-cycle cost including the additional adjustments described above for the first ten projects, the GAO determined three of the ten projects would cost more than the military construction option. Though more costly than the military construction option, DoD officials stated that the anticipated cost to the government would be less in the short term than the military construction option due to budget scoring (GAO 2002, 16-17).

As of the date of June 2012, the DoD has formally implemented most of the GAO's recommendations. The DoD currently mandates the considerations listed in Figure 3 in determining the life-cycle cost to the government.

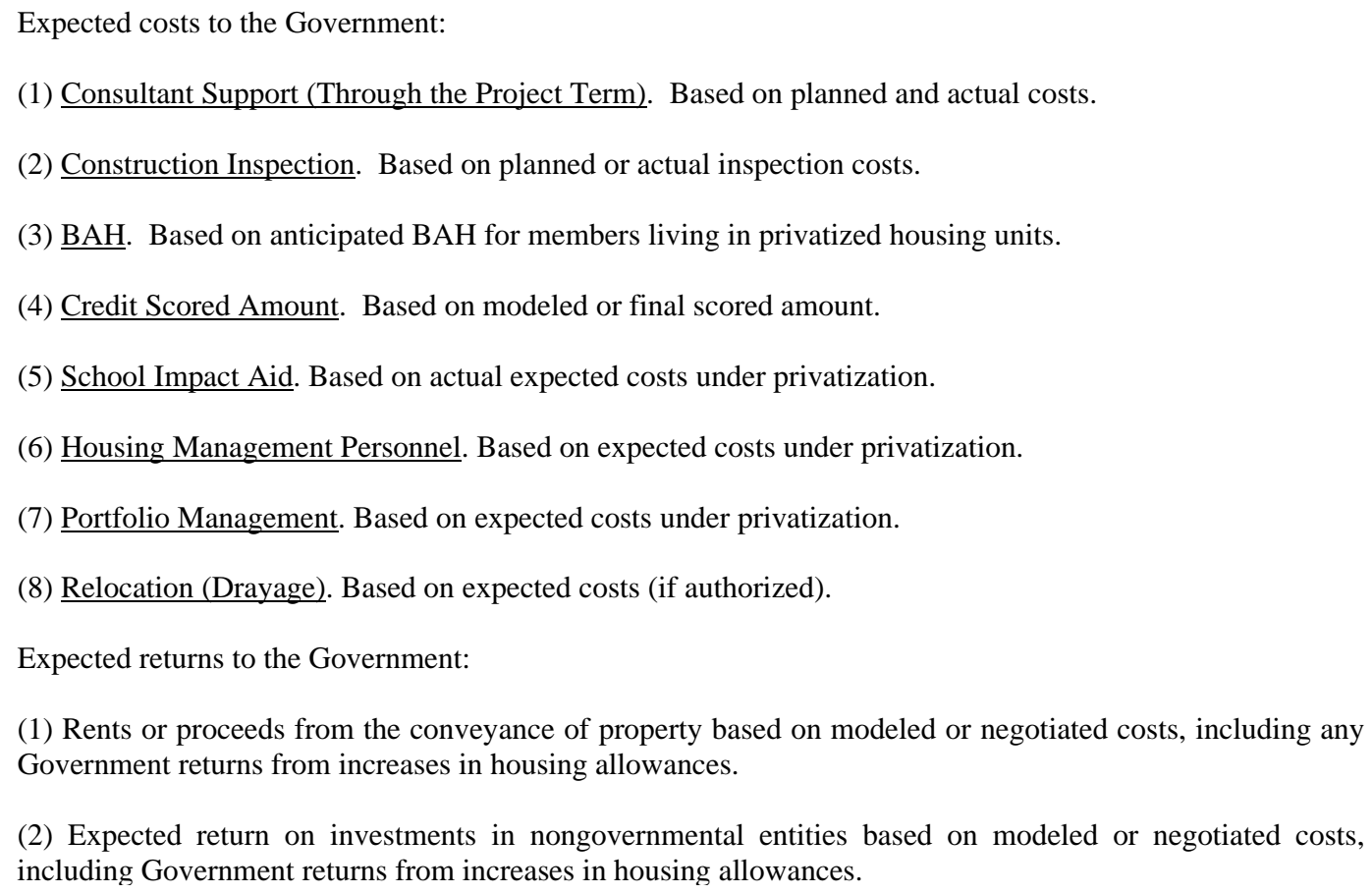

Figure 3. $\quad$ DoD Housing Management Manual Policy for Determining Life-Cycle Cost for the Privatization Option (After DoD 2010a). 


\section{CONCLUSION}

The services currently rely on privatization to help meet their housing needs. The MHPI has been effective at leveraging private investment to remedy the housing deficit over the past fifteen years. As Dr. Dorothy Robyn, DUSD(I\&E), recently reported to Congress (2012), "the Services have generated $\$ 29.7$ billion in construction to build new and renovate existing family housing units" with a government investment of only \$3.6 billion (Figure 4).

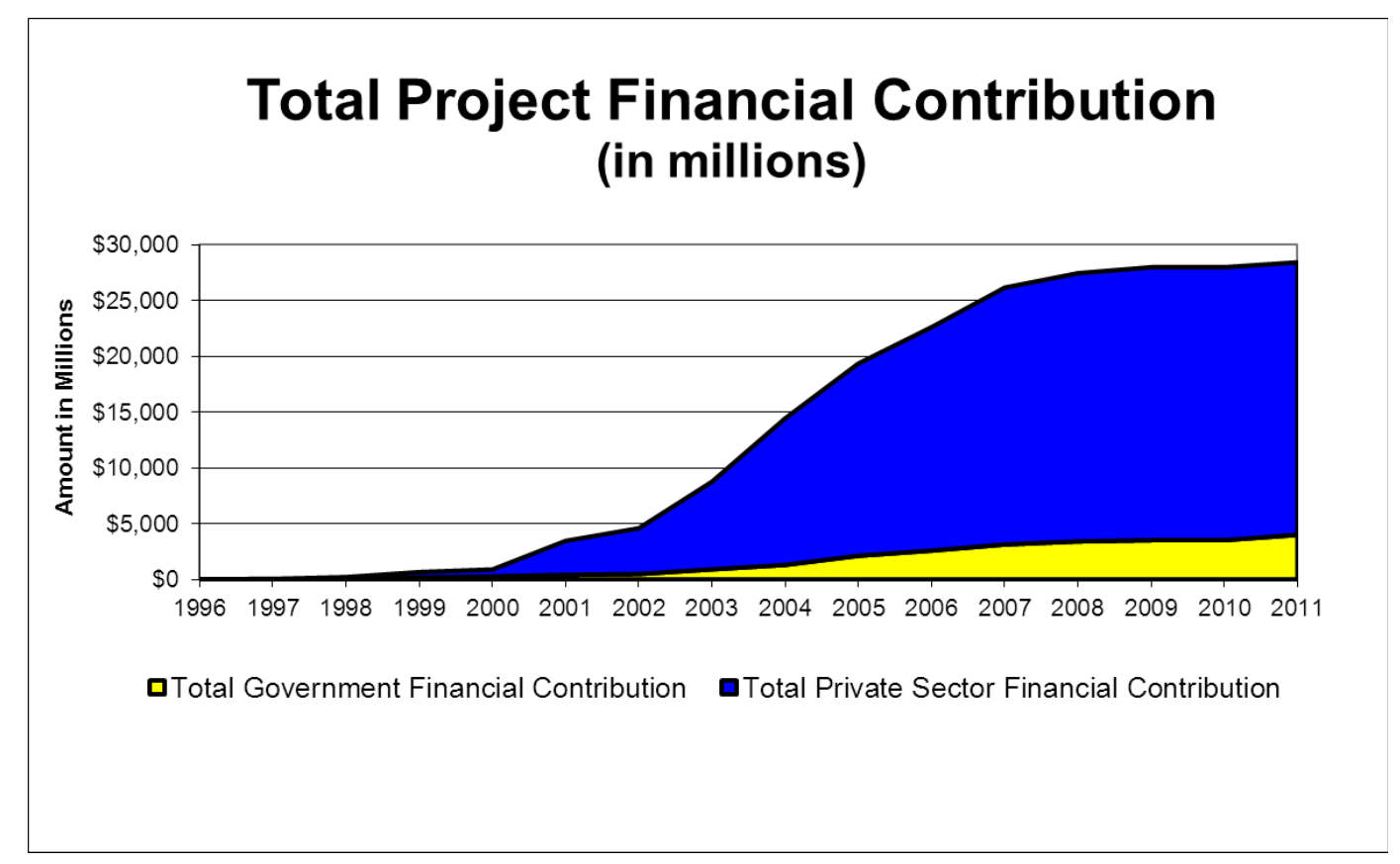

Figure 4. Total Project Financial Contributions (From DoD 2012)

The DoD has nearly achieved its goal of eliminating the approximately 200,000 inadequate homes over the course of fifteen years (Figures 5 and 6). Figure 6 also shows the number of units added to the total housing inventory to reduce the housing deficit (Deficit Reduction Units). 


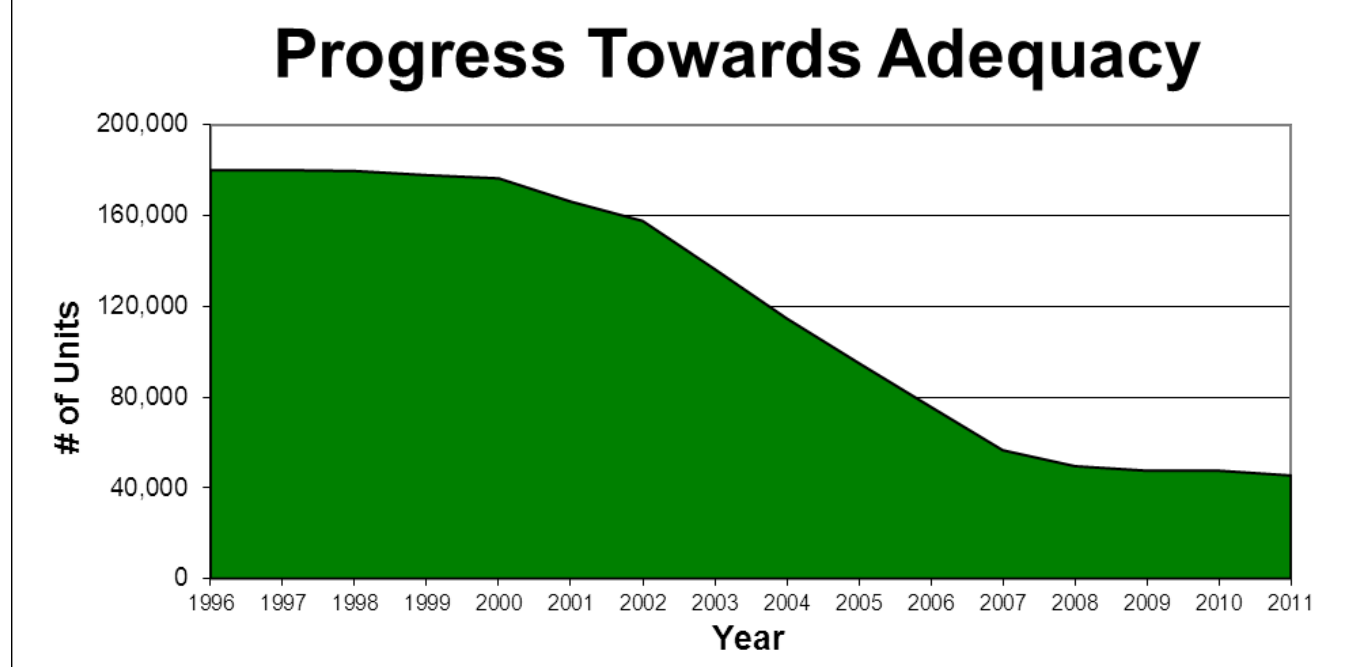

Figure 5. DoD’s Progress toward Adequate Housing (From DoD 2012)

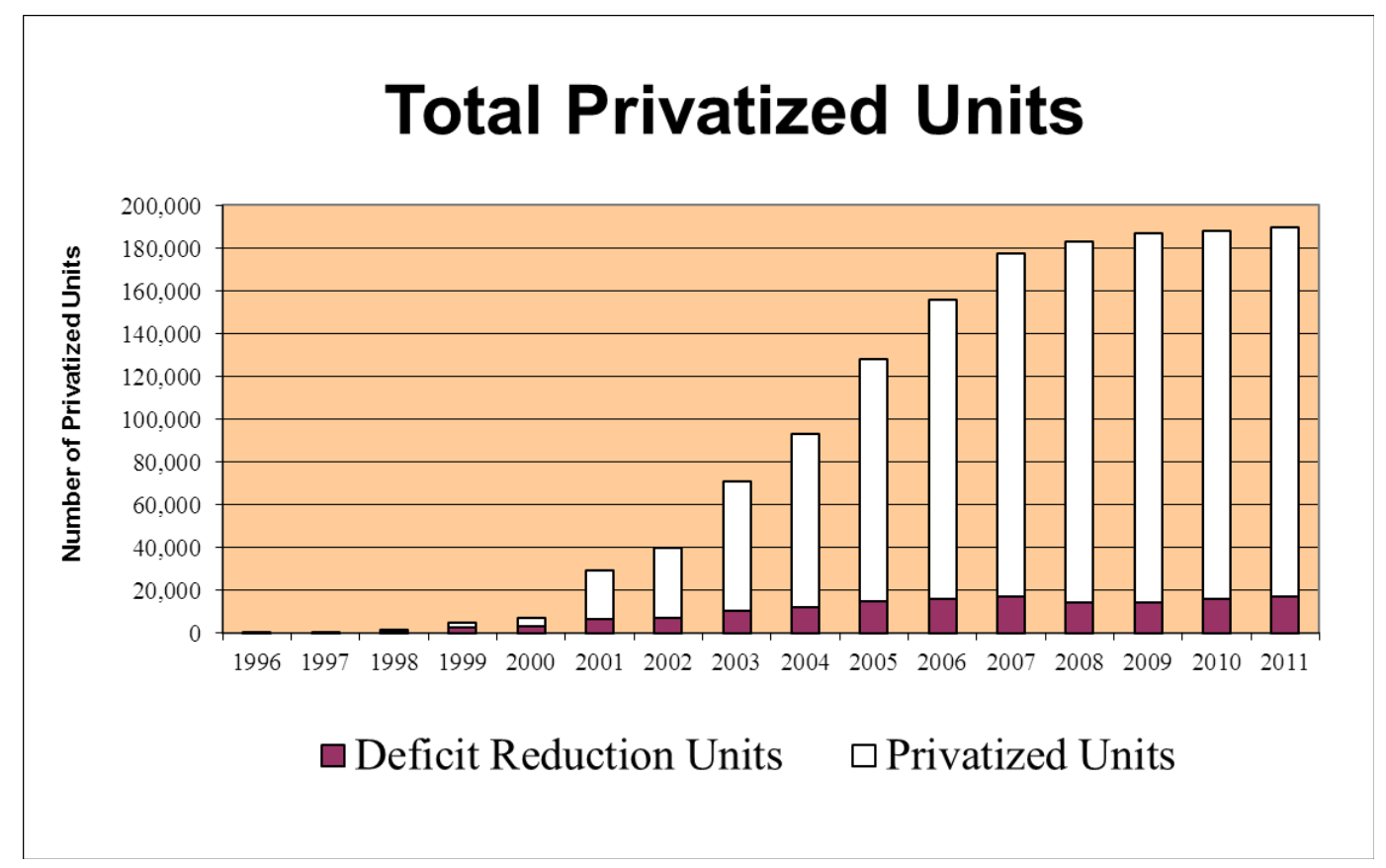

Figure 6. Total Privatized Units Since MHPI Inception (From DoD 2012) 


\section{LESSONS APPLIED TO MHPI}

Readiness is associated most closely with the morale and esprit de corps of U.S. Soldiers, Sailors, Airmen, and Marines. These intangibles are maintained by ensuring the best possible quality of life for people in uniform and their families. Quality of life falls into three general categories: standard of living for servicemembers; demands made on personnel, especially time away from family; and other ways people are treated while in the service.

—William J. Perry, Secretary of Defense

Based on the data presented in the previous chapters, the major lesson learned from the early housing privatization programs was that the DoD needed the flexibility to manage all the risks associated with private ventures. The DoD Risk Management Guide for DoD Acquisition (2006b, 1) defines risk as “a measure of future uncertainties in achieving program performance goals and objectives within defined cost, schedule and performance constraints.”

\section{A. IMPORTANCE TO THE ALTERNATIVE AUTHORITIES}

The MHPI has been successful because the service departments have had the proper tools (in the alternative authorizations) to manage risks unlike the four early privatization programs discussed in Chapter II. The one-size-fits-all approach used in the early privation programs introduced construction inefficiencies with federal housing standards preventing the use of local building practices, stymied continuous improvement due to fixed ceiling costs in the Wherry and Capehart programs, and prevented the adjustment of the fixed portions of Section 802 rents (Peeler et al. 2007, chap. 6, 112122; Baldwin 1996). Additionally, applying stringent requirements on developers provided too little incentive for them to continue participation (Baldwin 1996). For example, the Wherry program failed when sponsors lost interest in the program after tougher cost certification rules went into effect. Early privatization programs were not long-lasting because the $\mathrm{DoD}$ was not able to tailor levels of budget scoring or to

cultivate the environment necessary to motivate developers for the life of the project (Else 2001, 3-4). 
Because each project brings its own set of risks to the table, the services require flexibility to customize each venture by minimizing exposure to risks for both parties and maximizing positive sum outcomes. To make privatization work, the government uses the alternative authorizations to mitigate unfavorable outcomes for both the developers the government. Based on the data presented in previous chapters, Figure 7 depicts how the alternative authorities mitigate the risk root causes. 


\begin{tabular}{|c|c|c|c|c|}
\hline Cause of Risk & Risk Effect & Example & $\begin{array}{l}\text { Mitigating Alternative } \\
\text { Authorities }\end{array}$ & Principle \\
\hline $\begin{array}{l}\text { Project is unexpectedly very } \\
\text { successful. }\end{array}$ & $\begin{array}{l}\text { Developers earn windfall } \\
\text { profits. }\end{array}$ & $\begin{array}{l}\text { Some builders recouped } \\
\text { windfall profits under the } \\
\text { Wherry plan. }\end{array}$ & Investment (Joint Venture) & $\begin{array}{l}\text { Government has an equity } \\
\text { stake in the project, thereby } \\
\text { sharing all profits and losses } \\
\text { with the developer. Realized } \\
\text { gains are deposited in } \\
\text { Housing Improvement Fund. }\end{array}$ \\
\hline A project is behind schedule. & $\begin{array}{l}\text { Military housing is not } \\
\text { provided to service members } \\
\text { directly affecting readiness. }\end{array}$ & None available. & Interim Leases & $\begin{array}{l}\text { The government leases other } \\
\text { units in the project as the } \\
\text { project is completed. }\end{array}$ \\
\hline $\begin{array}{l}\text { A base closes or personnel } \\
\text { are reassigned. }\end{array}$ & $\begin{array}{l}\text { Project is no longer viable. } \\
\text { Developer defaults on loan. }\end{array}$ & $\begin{array}{l}\text { Some developers defaulted in } \\
\text { the Wherry and Capehart } \\
\text { programs. }\end{array}$ & Loan Guarantees & $\begin{array}{l}\text { If the developer defaults due } \\
\text { to re-assignment of military } \\
\text { personnel from the } \\
\text { installation, then the } \\
\text { developer can file a guaranty } \\
\text { claim (DoD 2010b). }\end{array}$ \\
\hline $\begin{array}{l}\text { Occupancy rates are below } \\
\text { sustainability due to market } \\
\text { forces. }\end{array}$ & \multirow[t]{2}{*}{$\begin{array}{l}\text { Project does not have the } \\
\text { necessary cash flow to } \\
\text { operate. }\end{array}$} & $\begin{array}{l}\text { Some Wherry projects } \\
\text { experienced high vacancy } \\
\text { rates when service members } \\
\text { favored Capehart units. Also, } \\
\text { conditions favoring home } \\
\text { ownership may cause a } \\
\text { decrease in renters. }\end{array}$ & $\begin{array}{l}\text { Assignment of Members } \\
\text { (Tenant Guarantee) }\end{array}$ & $\begin{array}{l}\text { Occupancy rate is forced } \\
\text { above the market rate. }\end{array}$ \\
\hline $\begin{array}{l}\text { Market conditions support } \\
\text { increased uncertainty with } \\
\text { tenant's ability to pay rent. }\end{array}$ & & None available. & Payment by Allotment & $\begin{array}{l}\text { Guarantees a stream of cash } \\
\text { flow. }\end{array}$ \\
\hline
\end{tabular}

Figure 7. Relationships between Risks and Alternate Authorities 


\begin{tabular}{|c|c|c|c|c|}
\hline Cause of Risk & Risk Effect & Example & $\begin{array}{l}\text { Mitigating Alternative } \\
\text { Authorities }\end{array}$ & Principle \\
\hline $\begin{array}{l}\text { Fiscal stress within the } \\
\text { government prevents } \\
\text { procurement of additional } \\
\text { housing. }\end{array}$ & $\begin{array}{l}\text { The services forego the } \\
\text { development of additional } \\
\text { housing units, thereby } \\
\text { directly affecting readiness. }\end{array}$ & \multirow{3}{*}{$\begin{array}{l}\text { Years of neglect lead to } \\
180,000 \text { inadequate housing } \\
\text { unit across DoD in the mid- } \\
1990 \text { 's. }\end{array}$} & $\begin{array}{l}\text { Conveyance or Lease of } \\
\text { Land/Units }\end{array}$ & $\begin{array}{l}\text { Conveyance or leasing of } \\
\text { these assets to the developer } \\
\text { is scored at zero percent. }\end{array}$ \\
\hline \multirow{2}{*}{$\begin{array}{l}\text { Government housing } \\
\text { standards prevent the } \\
\text { improvement of housing and } \\
\text { addition of amenities } \\
\text { comparable to civilian } \\
\text { housing in the surrounding } \\
\text { community. }\end{array}$} & \multirow[t]{2}{*}{$\begin{array}{l}\text { Tenants substitute away } \\
\text { from outdated military } \\
\text { housing and favor community } \\
\text { housing. }\end{array}$} & & $\begin{array}{l}\text { Conformity with similar local } \\
\text { housing units }\end{array}$ & $\begin{array}{l}\text { Military housing units built } \\
\text { under this authority will not } \\
\text { be subject to other housing } \\
\text { legislation and will be } \\
\text { comparable to housing in the } \\
\text { local area. }\end{array}$ \\
\hline & & & Ancillary support facilities & $\begin{array}{l}\text { Developers may build } \\
\text { supporting community } \\
\text { facilities. }\end{array}$ \\
\hline $\begin{array}{l}\text { Service members can not } \\
\text { afford adequate housing in } \\
\text { surrounding areas. }\end{array}$ & $\begin{array}{l}\text { Service members find } \\
\text { housing far from the } \\
\text { installation leading to long } \\
\text { commute times, affecting } \\
\text { quality of life, thereby } \\
\text { directly affecting readiness. }\end{array}$ & $\begin{array}{l}\text { In } 1985 \text {, developers chose to } \\
\text { purchase desirable, scattered } \\
\text { tracts of land for the Section } \\
801 \text { project at Fort Drum } \\
\text { which had commuting times } \\
\text { as long as } 60 \text { minutes } \\
\text { (Baldwin 1996). }\end{array}$ & $\begin{array}{l}\text { Differential lease payments } \\
\text { (DLP) }\end{array}$ & $\begin{array}{l}\text { The government will pay the } \\
\text { developer the difference } \\
\text { between BAH and market } \\
\text { rate. }\end{array}$ \\
\hline $\begin{array}{l}\text { Poor project management } \\
\text { leads to cutting corners and } \\
\text { wastage of funds. }\end{array}$ & $\begin{array}{l}\text { Housing is built below } \\
\text { standards. }\end{array}$ & None available. & Direct Loans & $\begin{array}{l}\text { The government provides the } \\
\text { developer with the direct } \\
\text { loan once the project is } \\
\text { completed and accepted by } \\
\text { the service. This limits } \\
\text { government financial } \\
\text { exposure during the } \\
\text { construction period (DoD } \\
\text { 2010b). }\end{array}$ \\
\hline
\end{tabular}

Figure 7. $\quad$ Relationships Between Risks and Alternate Authorities (continued) 


\section{B. RECOMMENDATION}

As a majority of privatization projects are completed and have been transitioned to the operations phase, the recommendation is to have a comprehensive review of all risks associated with the MHPI placing emphasis on sustainment of performance and continued customer satisfaction.

\section{CONCLUSION}

By having the necessary tools for managing stakeholders' risks, the services have the flexibility required to make privatization work given the increased uncertainty and complexity introduced when compared to using appropriated funds. Privatization of military housing has been successful in delivering the quality and quantity of housing required to ensure that service members quality of life enables them to focus on their mission. The ability for the government to provide adequate housing to service members and their families is directly tied to combat readiness (Defense Science Board 1995, 3-4). 
THIS PAGE INTENTIONALLY LEFT BLANK 


\section{APPENDIX. AUTHORITIES IN THE MILITARY HOUSING PRIVATIZATION INITIATIVE}

The following list describes the authorities of the MHPI as summarized in the GAO report of 1998.

- $\quad$ Direct loans: The DoD may make direct loans to persons in the private sector to provide funds for the acquisition or construction of housing units suitable for use as military family or unaccompanied housing. (10 U.S.C. 2873(a),(1))

- Loan guarantees: DoD may guarantee a loan to any person in the private sector if the proceeds of the loan are used to acquire or construct housing units suitable for use as military family or unaccompanied housing. (10 U.S.C. 2873(b))

- $\quad$ Build and lease: DoD may enter into contracts for the lease of military family or unaccompanied housing units to be constructed under the initiative. (10 U.S.C. 2874)

- Investments in nongovernmental entities: DoD may make investments in nongovernmental entities carrying out projects for the acquisition or construction of housing units suitable for use as military family or unaccompanied housing. An investment under this section may include a limited partnership interest, a purchase of stock or other equity instruments, a purchase of bonds or other debt instruments, or any combination of such forms of investment. (10 U.S.C. 2875(a),(b))

- Rental guarantees: DoD may enter into agreements with private persons that acquire or construct military family or unaccompanied housing units under the initiative to guarantee specified occupancy levels or to guarantee specific rental income levels. (10 U.S.C. 2876)

- Differential lease payments: Pursuant to an agreement to lease military family or unaccompanied housing to service members, DoD may pay the lessor an amount 
in addition to the rental payments made by military occupants to encourage the lessor to make the housing available to military members. (10 U.S.C. 2877)

- Conveyance or lease of existing property and facilities: DoD may convey or lease property or facilities, including ancillary supporting facilities, to private persons for purposes of using the proceeds to carry out activities under the initiative. (10 U.S.C. 2878)

- Interim leases: Pending completion of a project under the initiative, DoD may provide for the interim lease of completed units. The term of the lease may not extend beyond the project's completion date. (10 U.S.C. 2879)

- Conformity with similar local housing units: DoD will ensure that the room patterns and floor areas of military family and unaccompanied housing units acquired or constructed under the initiative are generally comparable to the room patterns and floor areas of similar housing units in the locality concerned. Space limitations by paygrade on military family housing units provided in other legislation will not apply to housing acquired under the initiative. (10 U.S.C. 2880(a),(b))

- Ancillary supporting facilities: Any project for the acquisition or construction of military family or unaccompanied housing units under the initiative may include the acquisition or construction of ancillary supporting facilities for the housing. (10 U.S.C. 2881)

- Assignment of members of the armed forces to housing units: DoD may assign service members to housing units acquired or constructed under the initiative. (10 U.S.C. 2882)

- Lease payments through pay allotments: DoD may require service members who lease housing acquired or constructed under the initiative to make lease payments by allotment from their pay. (10 U.S.C. 2882(c)) 


\section{LIST OF REFERENCES}

Alternate Authority for Acquisition and Improvement of Military Housing. U.S. Code 10 (2008), § 2871-2884.

Baldwin, W. C. 1996. "Four Housing Privatization Programs: A History of the Wherry, Capehart, Section 801, and Section 802 family housing programs in the Army.” http://www.acq.osd.mil/housing/docs/four.htm

Bissell, Kristie L., Robert L. Crosslin, and James L. Hathaway. 2010. Military Families and their Housing Choices. McLean, VA: LMI Government Consulting.

Buddin, R., C. R. Gresenz, S. D. Hosek, M. Elliott, and J. Hawes-Dawson. 1999. An Evaluation of Housing Options for Military Families. Washinggton: RAND.

Defense Science Board, Office of the Under Secretary of Defense Acquisition and Technology. 1995. Report of the Defense Science Board Task Force on Quality of Life. Washington: Department of Defense.

Else, Daniel H. 2001. Military Housing Privatization Initiative: Background and Issues. Washington: Congressional Research Service, The Library of Congress.

Inspector General, U.S. Department of Defense. 2008. DoD Section 801 On-Base Housing. Arlington, VA: Department of Defense.

O’Rourke, Ronald, and Stephen Daggett. 2007. Defense Procurement: Full Funding Policy - Background, Issues, and Options for Congress. Washington: Congressional Research Service, The Library of Congress.

Peeler, Kirsten, Christine Heidenrich, Katherine E. Grandine, and Dean A. Doerrfeld. 2007. Housing an Air Force and a Navy: The Wherry and Capehart Era Solution to the Postwar Family Housing Shortage (1949-1962). Frederick, MD: R. Christopher Goodwin \& Associates, Inc.

Twiss, Pamela C., and James A. Martin. 1998. Quality of Life and Shelter: A History of Military Housing Policy and Initiatives (1973 - 1996). Scranton, PA: Military Family Institute Marywood University.

U.S. Congress. Senate. 2012. Senate Appropriations Committee, Subcommittee on Military Construction, Veterans Affairs and Related Agencies. Statement of Dr. Dorothy Robyn, Deputy Under Secretary of Defense (Installations and Environment). 112th Cong., 2nd sess.

U.S. Department of Defense. 2006a. Military Housing Privatization Initiative (MHPI) 101. Office of the Deputy Under Secretary of Defense (Installations \& Environment). http://www.acq.osd.mil/housing/docs/mhpi101.ppt. 
—. 2006b. Risk Management Guide for DoD Acquisition, Sixth Edition.

_. 2010a. DoD housing Management Manual (4165.63-M). Office of the Deputy Under Secretary of Defense (Installations \& Environment).

- 2010b. Military housing Privatization Initiative Program Evaluation Plan Executive Report as of June 30, 2010. Office of the Deputy Under Secretary of Defense (Installations \& Environment).

- 2012. OSD housing update. Office of the Deputy Under Secretary of Defense (Installations \& Environment). http://www.acq.osd.mil/housing/docs/ PHMA2012-OSD\%20Perspective.pdf

U.S. General Accounting Office. 1986. Military family Housing: Observations on DoD Built-to-Lease and Rental-Guarantee Housing Programs. Washington, DC: Government Printing Office.

- 1996. Military Family Housing: Opportunities Exist to Reduce Cost and Mitigate Inequities. Washington, DC: Government Printing Office.

- 1998. Military housing: Privatization off to a Slow Start and Continued Management Attention Needed. Washington, DC: Government Printing Office.

- 2000. Military Housing: Continued Concerns in Implementing the Privatization Initiative. Washington, DC: Government Printing Office.

- 2001. Military Housing: DoD Needs to Address Long-Standing Requirements Determination Problems. Washington, DC: Government Printing Office.

- 2002. Military Housing: Management Improvements Needed as the Pace of Privatization Quickens. Washington, DC: Government Printing Office.

- 2004. Military Housing: Further Improvements Needed in Requirements Determinations and Program Review. Washington, DC: Government Printing Office.

- 2006. Military Housing: Management Issues Require Attention as the Privatization Program Matures. Washington, DC: Government Printing Office. 


\section{INITIAL DISTRIBUTION LIST}

1. Defense Technical Information Center

Ft. Belvoir, Virginia

2. Dudley Knox Library

Naval Postgraduate School

Monterey, California 